\title{
Dairy Buffalo Production and Management Systems in Haor Areas of Sylhet in Bangladesh
}

\author{
Mustasim Famous ${ }^{1, a, *}$, Md. Abdul Baset ${ }^{2, b}$, Md. Nazim Uddin²,c, Md. Nazmul Hossain, \\ Obaidul Islam $^{2, e}$, Shameema Khatun ${ }^{2, f}$, Mahfuza Ferdous ${ }^{3, g}$ \\ ${ }^{I}$ Department of Livestock Production and Management, Khulna Agricultural University, Khulna, Bangladesh \\ ${ }^{2}$ Department of Livestock Production and Management, Sylhet Agricultural University, Sylhet, Bangladesh \\ ${ }^{3}$ Faculty of Veterinary, Animal and Biomedical Sciences, Sylhet Agricultural University, Sylhet, Bangladesh
} ${ }^{*}$ Corresponding author

\begin{tabular}{l|l}
\hline A R T I C L E I N F O & A B S T R A C T \\
\hline $\begin{array}{l}\text { Research Article } \\
\text { Received : 28/03/2021 }\end{array}$ & $\begin{array}{l}\text { The aim of the study was to describe the scenario of the present condition of production and } \\
\text { management system of dairy buffalo at Haor areas of Sylhet in Bangladesh. Data were collected } \\
\text { between February 2019 and January 2020. Sixty dairy farmers and thirty indigenous dairy buffaloes } \\
\text { were selected for the study purpose. All respondent farmers were male and 65\% were in between } \\
40 \text { to 50 years of age. Parity number had a significant relation in response of body weight. Quality } \\
\text { analysis of milk showed that buffaloes which were reared at Haor areas have more fat content on } \\
\text { an average 7.88\% than buffaloes which were reared conventional dairy farm containing 7.34\%. } \\
\text { Price of buffalo's milk and meat were varied with the seasonal changes, lower in winter season. All } \\
\text { farmers fed the buffaloes only with green grass in winter. Four major diseases of buffaloes were } \\
\text { found in Haor areas where the percentage of foot and mouth diseases was 15.59\% followed by black } \\
\text { quarter (11.01\%), anthrax (7.34\%) and hemorrhagic septicemia (6.42\%). The buffaloes were not } \\
\text { dewormed so parasitic infestations dramatically increased and easily transferred from one to } \\
\text { another. The farmers had not enough knowledge about regular vaccination. But in contrast with } \\
\text { profitability, total benefit cost ratio from buffalo rearing was 1:1.56 annually. }\end{array}$ \\
$\begin{array}{l}\text { Keywords: } \\
\text { Buffalo } \\
\text { Dairy farm } \\
\text { Milk } \\
\text { Meat } \\
\text { Animal diseases }\end{array}$ &
\end{tabular}

\section{Introduction}

Livestock is one of the most important sub-sectors of agriculture in Bangladesh which plays a fundamental role in promoting public health and national economy of the country. Buffaloes hold a decisive place in overall livestock economy of Bangladesh (Sarkar et al., 2013). Buffalo is a multipurpose domestic animal providing high quality milk and meat, dung as fuel and organic fertilizer, mechanical or draft power and hides and skins as raw material for industry (Irshad et al., 2011). Buffaloes are better converter of poor-quality fibrous feeds to milk and meat. They are reported to have the capacity of digesting 5\% more crude fiber than high-yielding cows; and 4-5\% more efficient in utilizing metabolizable energy for milk production (Mudgal, 1989). In Bangladesh, the total buffalo population is about 1.493 million (DLS, 2020) of which coastal regions possess about $40 \%$ (Faruque et al, 1990). The per capita consumption of animal products is much higher in developed countries and substantial growths have also occurred in developing countries of Asia (FAO, 2009). Buffaloes in Bangladesh mainly classified into two categories: (i) indigenous buffaloes found in the coastal areas and marshy land of the country and (ii) migrated buffaloes from India and Myanmar found in the sugar-cane belt and Cox's bazar district, respectively (Saadullah, 2012). The migrated buffaloes from India are generally of river types, and from Myanmar, coastal areas or marshy land are of swamp types, though a number of crossbred between swamp and river types are found in the coastal area (Faruque, 1990; Faruque, 1992). There is no recognized breed of water buffaloes in Bangladesh and these are mainly indigenous non-descriptive types (Faruque, 1990). However, two predominant types of buffaloes commonly available in Bangladesh such as riverine and swamp types (Sarwar et al., 2002). In general, buffalo is regarded as more productive, healthier and more useful than the cow, especially for the poorest "backyard" farmers in Asia. The buffaloes, apart from sporadic distribution all over the country, are available in a higher concentration in some areas, especially; the availability of pastures favors their concentration. A Buffalo pasture, 
locally called Bathan, is a common land where the animals are kept for a major period of a year. The Buffalo raised in other than Bathan is termed as non-Bathan system. Haor areas of Sylhet are one of the largest belts of Bangladesh where management practices of buffalo are the most popular among the local farmers but there are no documented research studies so far that investigated the scopes and opportunities of buffalo production in Haor areas and the ultimate profit gain by the farmers. The study was performed to know the overall production and management system of dairy buffalo in Haor areas.

\section{Materials and Methods}

Sylhet is a district to the North-East of Bangladesh. This region of Bangladesh is unique due to its hydroecological characteristics and special natural features of wetland which is called Haor. Haor of Sylhet is surrounded by Habiganj District in the west, Sylhet District in the north and Indian states of Assam and Tripura in the east and south respectively. Data were collected between February 2019 and January 2020. A list of buffalo farmers was collected from District Livestock Office, where farmers went for the training and treatment of buffalo. Buffalo were categorized into two groups, one is Haor buffalo that is reared at the Haor basin area and another one is Farm buffalo which is reared at homestead by conventional method. Thirty indigenous dairy buffaloes from Haor were conveniently selected and categorized into three groups based on live weight, milk yield and parity. Live weight and milk yield were measured by Portable Digital Animal Weighing Scale (Baset et al., 2012) and top loading balance respectively. Randomized block design was performed. Diseases were diagnosed at Veterinary hospital by clinical signs and symptoms. Data of Socioeconomic traits, parity, health care and profitability were collected through questionnaire. Type of interview was direct from the farmers and physical observation to collect the information of feeding practice. Favorable friendly situation was with the farmers. Total solids (TS \%), protein
(\%), $\mathrm{pH}$ and fat (\%) of the mornings milk samples were tested at laboratory by using milk analyzer machine. All questionnaires were cross examined from other members of the owner's family. Tabular method and statistical analysis were done by using IBM SPSS software.

\section{Results and Discussion}

Socioeconomic status of buffalo farmers: In Haor areas it was evident that $46.67 \%$ farmers are landless ( $<0.2$ ha.), they haven't enough land to rear buffalo as well as for resident. Only 5\% farmers were found as medium (1.013.04 ha.) as shown in Table 1. There were five categories of farmers named Landless farmer (less than 0.2 ha.), Marginal Farmer (0.2-0.61 ha.), Small Farmer (0.61-1.01 ha.), Medium Farmer (1.01-3.04 ha.) and Large Farmer (above 3.04 ha.) (BBS, 2015). In Haor areas there were $46.67 \%$ landless farmers followed by $20 \%$ small and $15 \%$ marginal farmers. In our study it was revealed that $65 \%$ of the farmers were in range of 40-50 years. Siddiki et al. (2015) reported majority of the buffalo farmers were 30-40 years of age which disagree with our study, here young people of below 30 years were not so much interested about buffalo rearing in Haor areas, they had appetency to go London for that $65 \%$ of farmers were in $40-50$ years of age. Female were involved only with the household activities and all the farmers were male. In Haor areas $45 \%$ farmers have the qualification of primary school level which is in line with the Nithya and Selvaraj (2018) who stated that buffalo rearing farmers were mainly primary level (40\%) followed by secondary level $(33.33 \%)$ and college level $(11.66 \%)$ at Tripur district of Tamil Nadu. The occupational status of the buffalo farmers of Subornochor upazila in Noakhali were $68 \%$ agriculture along with buffalo rearing (Amin et al., 2015) and $30 \%$ of the buffalo farmers of Bagerhat fully depended on buffalo rearing (Sarkar et al., 2013). But in Haor areas of Sylhet, 70\% respondents took agriculture and $21.67 \%$ sorted small business as their subsidiary occupation.

Table 1. Socioeconomic status of dairy buffalo farmer in Haor of Sylhet $(\mathrm{N}=60)$

\begin{tabular}{|c|c|c|c|}
\hline & Items & Frequency & Percentage \\
\hline \multirow{5}{*}{ Farmer Types } & Landless Farmer (<0.2 ha.) & 28 & 46.67 \\
\hline & Marginal Farmer (0.2-0.61 ha.) & 9 & 15 \\
\hline & Small Farmer (0.61-1.01 ha.) & 12 & 20 \\
\hline & Medium Farmer (1.01-3.04 ha.) & 3 & 5 \\
\hline & Large Farmer (above 3.04 ha.) & 8 & 13.33 \\
\hline \multirow{4}{*}{ Age } & $<30 \mathrm{y}$ & 7 & 11.67 \\
\hline & $30-40 y$ & 3 & 5 \\
\hline & $40-50 y$ & 39 & 65 \\
\hline & $>50 \mathrm{y}$ & 11 & 18.33 \\
\hline \multirow{2}{*}{ Gender } & Male & 60 & 100 \\
\hline & Female & 0 & 0 \\
\hline \multirow{4}{*}{ Education } & Illiterate & 12 & 20 \\
\hline & Primary School & 27 & 45 \\
\hline & Secondary School & 15 & 25 \\
\hline & Graduated & 6 & 10 \\
\hline \multirow{4}{*}{$\begin{array}{l}\text { Subsidiary } \\
\text { Occupation }\end{array}$} & Agriculture & 42 & 70 \\
\hline & Servicing & 3 & 5 \\
\hline & Business & 13 & 21.67 \\
\hline & Others & 2 & 3.33 \\
\hline
\end{tabular}


Table 2. Descriptive statistics of body weight, milk yield by parity

\begin{tabular}{|c|c|c|c|c|c|c|}
\hline \multirow{2}{*}{ Parameters } & \multicolumn{4}{|c|}{ Parity } & \multirow{2}{*}{ SEM } & \multirow{2}{*}{ P-Valuc } \\
\hline & 1 & 2 & 3 & 4 & & \\
\hline Body Weight (Kg) & $365.72^{\mathrm{b}}$ & $369.75^{\mathrm{b}}$ & $431.19^{\mathrm{a}}$ & $439.61^{\mathrm{a}}$ & 8.31 & 0.001 \\
\hline Milk yield(L/d) & 1.78 & 2.06 & 2.20 & 1.45 & 0.15 & 0.781 \\
\hline
\end{tabular}

SEM = Standard Error Mean

Table 3. Comparative analysis of buffalo milk at Haor areas and farms

\begin{tabular}{l|ccc}
\hline \multirow{2}{*}{ Traits } & \multicolumn{2}{c}{ (Mean \pm SE) } & \multirow{2}{*}{ P-Value } \\
\cline { 2 - 3 } & From Farm & From Haor & 0.003 \\
$\mathrm{pH}$ & $6.55 \pm 0.122$ & $6.82 \pm 0.103$ & 0.001 \\
Fat $(\%)$ & $7.34 \pm 0.159$ & $7.88 \pm 0.357$ & 0.001 \\
Protein $(\%)$ & $4.24 \pm 0.34$ & $3.86 \pm 0.107$ & 0.001 \\
Total solids $(\%)$ & $16.33 \pm 0.146$ & $17.79 \pm 0.563$ & \\
\hline
\end{tabular}

$\mathrm{SE}=$ Standard Error

Table 4. Seasonal difference at price of milk and meat

\begin{tabular}{|c|c|c|c|}
\hline \multirow[b]{2}{*}{ Parameters } & \multicolumn{2}{|c|}{ Season $($ Mean \pm SE) } & \multirow[b]{2}{*}{ P-Value } \\
\hline & $\begin{array}{l}\text { Wet (April - September)/ } \\
\text { USD }\end{array}$ & $\begin{array}{l}\text { Dry (October- March)/ } \\
\text { USD }\end{array}$ & \\
\hline Price of milk/L & $0.65 \pm 0.059$ & $0.47 \pm 0.044$ & 0.001 \\
\hline Price of meat $/ \mathrm{Kg}$ & $5.86 \pm 0.42$ & $5.32 \pm 0.36$ & 0.001 \\
\hline
\end{tabular}

USD $=$ United States Dollar, $\mathrm{SE}=$ Standard Error

Housing system and purpose of rearing: In Haor areas $61.67 \%$ farmers reared buffalo only for meat purpose, their main target was to sell out buffalo at the high time of price after growing up one to two years. $38.33 \%$ respondents reared buffalo for both milk and meat purpose. Farmers did not follow any other housing system except extensive system and reared buffalo for the purpose of meat where milk yield was considered as an extra income or salary to the labor. This study is analogous to the report of Uddin et al. (2016). Our study reveals that all the farmers of Haor areas reared dairy buffalo in free area called Bathan as there was available source of grass which is commonly known as extensive housing system. In early decades buffalo rearing for draught purpose were common but through the invention of technology it was gradually decreased. Majority of the respondents kept their buffaloes mainly at Bathan and very little percentage of the farmer practiced semi- intensive system in the study areas (Amin et al., 2015). This study was more likely similar to our study as all farmers followed extensive housing system.

Relation of body weight and milk yield with parity: The relation of body weight and parity was statistically highly significant whereas there was non-significant relation between milk yield and parity in Haor areas $(\mathrm{P}<0.001)$. Normally parity is related to the age of animal. In our research, it revealed that there was significant relationship between parity and body weight (Table 2). Body weight gradually increased in response to parity. Kelsey et al. (2003) reported the significant relationship of milk yield with parity and stage of lactation but in our research milk yield and parity had no significant relationship because lactation stages were not recorded, and farmers were not conscious about supplying adequate nutrients for high yielding.

Chemical composition of buffalo milk both at Haor and farm: From the Table 3, it is shown that there was significant difference of $\mathrm{pH}$, Fat (\%), Protein (\%), Total solid (\%) between milk source from farm and Haor. The value of Fat $(\%)$ in buffalo milk collected form commercial buffalo farm was 7.34 and from the buffalo of Haor areas was 7.88. Hamid et al. (2016) reported that buffalo milk contains less water, more total solids, fat and protein, slightly more lactose than cow's milk. It seems more intense than cow's milk because it generally contains more than $16 \%$ total solids compared with $12-14 \%$ for cow's milk. In addition, its fat content (6-8\%) is usually $50-60 \%$ higher (or more) than cow's milk. Buffalo milk is healthy as it is richer in saturated fatty acids, higher fat, protein, calcium and more tocopherol which is a natural antioxidant (Habib et al., 2017). That is analogous to the study findings of milk composition from both Haor areas and farm. But percentage of fat in Haor areas buffalo milk was more than the source of milk from farm as well as showed a highly significant difference. It was because, in Haor areas buffalo had free movement for grazing and natural grass was the main source of feed for Haor areas dairy buffalo.

Seasonal difference at price of milk and meat: Price of milk and meat had level of significance compared to dry and wet season variance. Price vary from season to season in Haor areas. Particularly in dry (October - March) season average price of per liter milk and per kg meat was $0.65 \$$ and $5.86 \$$ respectively but in case of wet (AprilSeptember) season it was decreased to $0.47 \$ / \mathrm{L}$ milk and $5.31 \$ / \mathrm{Kg}$ meat (Table 4). Because of the higher milk fat contents, buffalo milk is preferred over cow milk and fetches better price in milk market (Sarwar et al., 2002; Khan et al., 2008). In wet season available source of grass were less than the dry season when buffalo were reared in Bathan at dry season. For this reason, milk yield reduced and as demand market price increased. In case of meat price, in dry season people were more interested to buy buffaloes. This was responsible to increase the price of meat or buffalo than wet season when buffalo reared in homestead. 
Table 5. Feeding practices followed by farmers at Haor

\begin{tabular}{|c|c|c|c|c|}
\hline Sl. No. & \multicolumn{2}{|c|}{ Application } & Wet season $(\%)$ & Dry season $(\%)$ \\
\hline \multirow{2}{*}{1} & \multirow{2}{*}{ Feeding balanced ration } & Yes & 5 & 0 \\
\hline & & No & 95 & 100 \\
\hline \multirow{4}{*}{2} & \multirow{4}{*}{ Feed supply } & Grass & 88.3 & 100 \\
\hline & & Roughage & 0 & 0 \\
\hline & & Concentrate & 0 & 0 \\
\hline & & Mixture of feed & 11.7 & 0 \\
\hline \multirow{2}{*}{3} & \multirow{2}{*}{ Water supply } & Yes & 76.7 & 0 \\
\hline & & No & 23.3 & 100 \\
\hline \multirow{2}{*}{4} & \multirow{2}{*}{$\begin{array}{l}\text { Additional diet in pregnancy and } \\
\text { lactation }\end{array}$} & Yes & 46.7 & 0 \\
\hline & & No & 53.3 & 100 \\
\hline \multirow{2}{*}{5} & \multirow{2}{*}{ Feeding mineral supplements } & Yes & 21.7 & 0 \\
\hline & & No & 78.3 & 100 \\
\hline
\end{tabular}

Table 6. Diseases, Health care and breeding practices of buffaloes in Haor

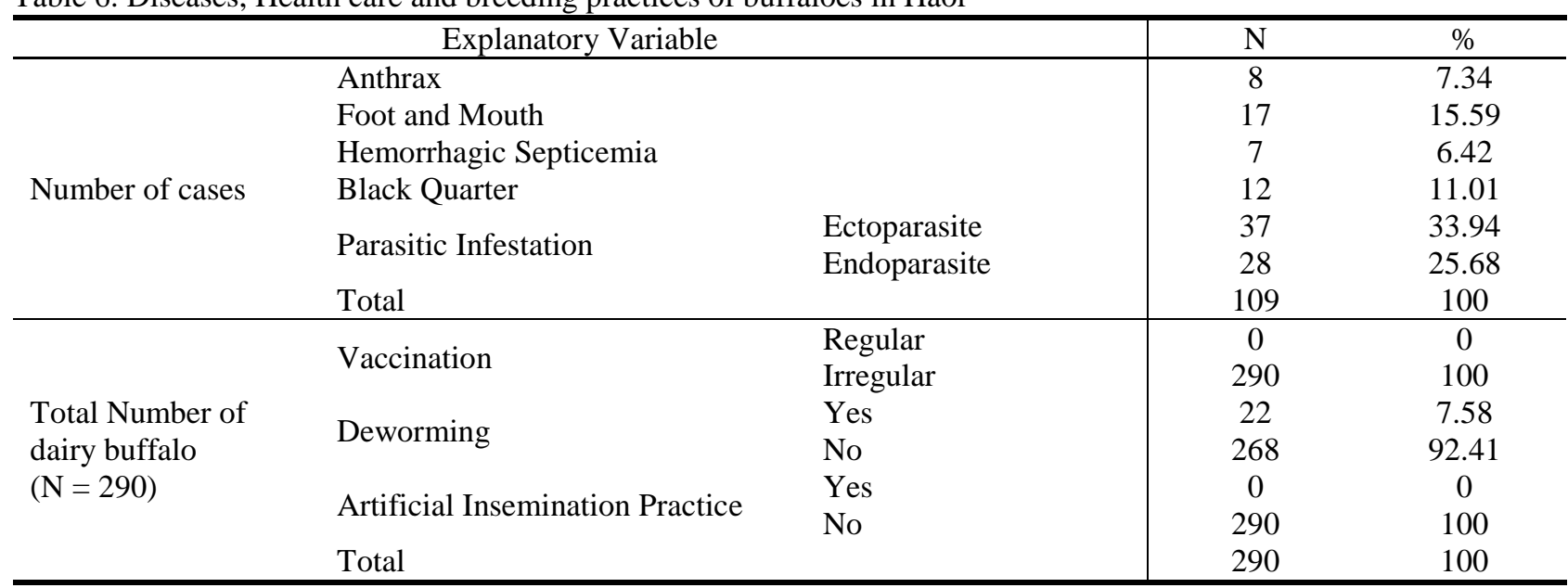

Feeding practices at Haor: In Haor feeding management practices depend on the seasonal variation where there is availability of grass in Haor in change of season or not. Only 5\% farmer supplied balanced ration in combination of roughage and concentrate to the dairy buffaloes in wet season where farmers $(95 \%)$ had no about balance ration formulation (Table 5). It was found that all farmers $(100 \%)$ fed only green fodder during dry season when grass was available in the Haor. Haor is flooded in wet season and huge scarcity of green grass, but $88.3 \%$ farmers fed grass from roadside and high land. None of the farmers at Haor practiced silage making or any other special treatments like chaffing, soaking or urea treating paddy straw and they only fed grass both wet and dry season. Kamboj and Tomar (2000) as well as Sahu (2001) stated that farmers did not applied feeding or feeding minimum quantities of concentrates to their buffaloes. This is in line of our study. There was not any supply of concentrate to dairy buffalo at Bathan and only 5\% supply concentrate at homestead however Garg et al. (2005) reported, $59.72 \%$ farmers fed poor quality concentrates. It is totally analogous to our study findings. The present results clearly indicated that there was a lot of scope for improvement of buffalo performance by better feeding. There was dramatically difference in additional allowance of concentrate during pregnancy. At Haor, in dry season there was no additional supply of feed in pregnancy and lactation but at wet season in owner's home $46.7 \%$ dairy buffalo was supplied additional concentrate in pregnancy and lactation case. Garg et al. (2005) also observed that
$62.5 \%$ farmers did not feed mineral mixture or feed supplements to their dairy animals and $11.25 \%$ farmers providing additional concentrates to pregnant animals in rural areas of Baran district of Rajasthan. The non-feeding of additional supplements to the pregnant animals and of mineral mixture to all animals clearly indicates that productive animals were facing shortages of nutrients which would inhibit their exhibiting their performance. This might have been due to a lack of scientific feeding knowledge among the buffalo farmers, high costs and feed and mineral mixtures or non-availability etc.

Diseases, health care and breeding practices: Four major diseases of buffaloes were found where the incidence of foot and mouth diseases (FMD) was $15.59 \%$ followed by black quarter (BQ) (11.01\%), anthrax $(7.34 \%)$, and hemorrhagic septicemia (HS) $(6.42 \%)$ as shown in Table 6 . However, very dangerous scenario was found that all the farmers of the selected area were totally unaware about de-worming and vaccination. Parasitic infestation both ecto and endo parasites (tick, lice, mice, round worm, tape worm, lung worm) were noticed highly. As buffalo were housed together in open land, parasitic infestations dramatically increased and easily transfer from one to another. It is noticed that $92.41 \%$ farmers were not interested to give any anthelmintic to their buffaloes. Incidence of diseases is a major constraint of livestock production which not only reduces the productivity but also causes economic loss. In our study four major disease FMD (15.59\%), BQ (11.01\%), Anthrax (7.34\%) and HS $(6.42 \%)$. No buffalo farmers were claimed for early or 
endemic mastitis. Sarker et al. (2013); Mitra et al. (1995) and Gupta et al. (2014) also reported that a serious threat of infectious diseases like FMD, HS and BQ in animals were the main problem. Ali and Sultana (2012) stated $16.25 \%$ HS cases in buffaloes at Dinajpur. These are almost similar to our research findings. Artificial insemination (AI) yet not recognized in Haor areas.

Profit from buffalo: Average total cost per buffalo was estimated at USD 858.57\$ annually. Feed, labor, medicine and transportation cost were included in this calculation. It was found that transportation cost only required during selling period of buffalo. The return from dairy buffalo consisted of selling of milk and selling out dairy buffalo. The average sale price of milk was calculated based on the average lactation period (228 days), average return from milk selling was calculated at USD $77.59 \$$ and the profit from buffalo selling was at USD 1264.17\$ (Shown at Table 7). The total earning from dairy buffalo was $1341.76 \$$ annually. It was highly profitable at coastal belt areas of Bhola and a crucial pathway for poverty alleviation reported by Hasan et al. (2016). The annual food and cloth purchasing of buffalo farmers of Bagerhat District increased to $62.85 \%$ and $58.33 \%$ respectively (Sarkar et al., 2013). The annual total cost of buffalo production at Subornochor Upazilla of Noakhali was 74.92\$, while gross return was $164.38 \$$ and food purchasing capacity of buffalo farmers was increased 58\% (Amin et al., 2015). Regarding all, the study also revealed that buffalo rearing at Haor areas was highly profitable as cost benefit ratio was $1: 1.56$.

Table 7. Profitability table of dairy buffalo

\begin{tabular}{ll|c}
\hline & \multicolumn{1}{c|}{ Category } & USD \\
\hline & Purchase of buffalo & 784.06 \\
& Feed cost & 39.09 \\
Average cost / buffalo /year & Labor cost & 15.81 \\
& Medicine and vaccine cost equipment & 5.21 \\
& Transportation cost & 14.40 \\
& Total & 858.57 \\
\hline \multirow{2}{*}{ Return from / buffalo /year } & Average return from milk & 77.59 \\
& Average return by selling out buffalo & 1264.17 \\
\hline Net profit / buffalo & Total & 1341.76 \\
Per buffalo annual cost benefit ratio = (Return from per buffalo per year /average cost of per buffalo per year) & 483.18 \\
\hline
\end{tabular}

\section{Conclusion}

Considering all the parameters, dairy buffalo rearing is profitable practice in the Haor areas as there is the availability of grass. Dairy buffalo rearing also improves the socio-economic status of buffalo farmers. Milk yield from dairy buffalo is lower but chemical composition of milk where fat $\%$ is good. With adequate nutrition at diet milk yield can be increased. So, it can be recapitulating that by providing proper care and management buffalo can contribute more to the economy of Bangladesh.

\section{Acknowledgment}

Authors would like to gratitude to the ministry of Science and Technology of Bangladesh (National Science and Technology fellowship 2018-19, Serial No: 33 Id no:395, awarded to the corresponding author) for funding the research.

\section{References}

Ali MZ, Sultana S. 2012. Isolation and identification of bacteria from tracheas and lungs of buffaloes in Dinajpur. Stam. J. Microbiol., 2: 31-33.

Amin MR, Siddiki MA, Kabir AKMA, Faruque MO, Khandaker ZH. 2015. Status of buffalo farmers and buffaloes at Subornochar upozila of Noakhali district in Bangladesh. Progressive Agriculture, 26: 71-78.

Baset MA, Haque KS, Sarker NR, Hossain MM, Alam S. 2012. Portable Digital Animal Weighing Balance. Animal Production Research Division, BLRI, Savar, Dhaka.

BBS, 2015. Bangladesh Bureau of Statistics, Government of Bangladesh, Bangladesh.
DLS, 2020. Annual Report on Livestock, Division of Livestock Statistics, Ministry ofAgriculture.

Faruque MO, Hasnath MA, Siddique NN. 1990. Present status of buffaloes and their productivity in Bangladesh. AsianAustralas J. Anim. Sci., 3: 287-292. DOI: https://doi.org/ 10.5713/ajas.1990.287

Faruque MO. 1992. Buffalo development in BangladeshDevelopment of intermediate technologies for selective breeding of village herds. Final report of research project of NST, Dhaka.

FAO, 2009. Food and Agricultural Organization. The State of Food and Agriculture. Change in the Livestock Sector.

Garg MK, Jain LS, Chaudhary JL. 2005. Studies on housing, feeding and milking management practices of dairy cattle in Baran district of Rajasthan. Indian J. Dairy Sci., 58:123-128.

Gupta JJ, Singh KM, Bhatt BP, Dey A. 2014. A Diagnostic Study on Livestock Production System in Eastern Region of India. ICAR Research Complex for Eastern Region P.O. Bihar Vet. College, Patna-800014 (Bihar).

Habib MR, Haque MN, Rahman A, Aftabuzzaman M, Aliand MM, Shahjahan M. 2017. Dairy buffalo production scenario in Bangladesh: a review. Asian J. Med. Biol. Res., 3(3): 305316. doi: 10.3329/ajmbr.v3i3.34518

Hamid MA, Siddiky MNA, Rahman MA, Hossain KM. 2016. Scopes and Opportunities of Buffalo Farming in Bangladesh : A Review. SAARC J. Agri., 14(2): 63-77.

Hasan T, Akter S, Biswas H, Halim MA, Alam A, Rafiq K. 2016. Economic analysis of small-scale dairy buffalo enterprises in Bhola district of Bangladesh. Progressive Agriculture, 27 (4): 502-510.

Irshad A, Tariq MM, Bajwa MA, Abbas F, Isani GB, Soomro GH, Waheed A, Khan KU. 2011. A study on performance analysis of Holstein-Friesian cattle herd under semi-intensive management at Pishin Dairy Farm Balochistan. J. Inst. Sci. Techno., Igdir, Turkey, 1: 53-57. 
Kamboj ML, Tomar OS. 2000. Feeds and feeding managemental practices of Nagori cattle under field conditions. Indian $\mathbf{J}$ Anim. Prod. Manag., 16:129-131.

Kelsey JA, Corl BA, Collier RJ, Bauman DE. 2003. The Effect of Breed, Parity and Stage of Lactation on Conjugated Linoleic Acid (CLA) in Milk Fat from Dairy Cows. J. Dairy Sci., 86(8): 2588-2597.

Khan S, Qureshi MS, Ahmad N, Amjed M, Durrani FR, Younas M. 2008. Effect of pregnancy on lactation milk value in dairy buffaloes. Asian-Australas J. Anim. Sci., 21: 523-531.

Mitra M, Ghosh D, Ali K, Guha C, Pramanik AK. 1995. Prevalence of sub-clinical mastitis in an organized buffalo farm at Haringhata. Indian Vet. J., 72: 1310-1311.

Mudgal VD. 1989. The role of riverine buffaloes in small farm systems in Asia. Proceeding of Symposium Buffalo Genotypes for Small Farms in Asia, University of Pertinian, Malaysia. pp.1-9.

Nithya P, Selvaraj R. 2018. An analysis of constraints faced by farmers in rearing buffaloes in Tripur district of Tamil Nadu. Int. J. Sci. Env. Tech., 7(5): 1655-1661.
Saadullah M. 2012. Buffalo production and constraints in Bangladesh. The J. Anim. Plant Sci., 22(3): 221-224.

Sahu SP. 2001. The buffalo management practices followed by the farmers of Karnal and Kurukshetra district of Haryana. M.V.Sc. Thesis, Haryana Agricultural University, Hisar, India.

Sarkar S, Hossain M, Amin M. 2013. Socio-economic status of buffalo farmers and the management practices of buffaloes in selected areas of Bagerhat District of Bangladesh. Bang. J. Anim. Sci., 42(2): 158-164.

Sarwar M, Khan MA, Nisa M, Iqbal Z. 2002. Dairy industry in Pakistan: A Scenario. Intl. J. Agric. Biol, 3: 420-428.

Siddiki MA, Amin MR, Kabir AKMA, Faruque MO, Khandaker ZH. 2015. Socio-economic status of buffalo farmers and the performances of buffaloes at Lalpur Upozila of Natore district in Bangladesh. Bang. J. Anim. Sci., 44: 157-165.

Uddin MK, Mintoo AA, Awal TM, Kondo M, Kabir AKMA. 2016. Characterization of buffalo milk production system in Bangladesh. Bang. J. Anim. Sci., 45: 69-77. 